\title{
Effect of Gum Arabic Coatings on Physico-Chemical and Sensory Qualities of Guava (Psidium guajava L) cv. Shweta
}

\author{
P.S. Gurjar*, Bharati Killadi, J. Lenka and D.K. Shukla \\ Division of Post-Harvest Management, ICAR-Central Institute for Subtropical Horticulture, \\ Rehmankhera, Lucknow, Uttar Pradesh, India \\ *Corresponding author
}

\section{A B S T R A C T}

\begin{abstract}
An experiment was conducted to study the effect of gum arabic $(2.5,5$ and $10 \%)$ coatings on physicochemical and sensory qualities of guava (Psidium guajava $\mathrm{L} \mathrm{cv}$. Shweta) during storage at ambient conditions (average day/night temperature $21.5 / 12.8{ }^{\circ} \mathrm{C}$ and humidity $52 \%$ ) for 9 days. The physical and biochemical observations were recorded at 3 days interval during storage. The gum arabic (GA) $10 \%$ coating significantly reduced physiological loss in weight (PLW) and retained higher firmness, ascorbic acid, peel chlorophyll content and marketable fruits as compared to control. The minimum PLW $(15.41 \%)$ and the maximum ascorbic acid $(181.7 \mathrm{mg} / 100 \mathrm{~g}$ pulp), peel chlorophyll $(72.55 \pm 4.10 \mathrm{mg} / \mathrm{g})$ and firmness $\left(8.12 \pm 1.67 \mathrm{~kg} / \mathrm{cm}^{2}\right)$ were observed in GA $10 \%$ coated fruits, while uncoated fruits reported to having higher PLW (19.23\%) and lower ascorbic acid $(126.1 \mathrm{mg} / 100 \mathrm{~g})$, peel chlorophyll $(36.21 \pm 3.54 \mathrm{mg} / \mathrm{g}$ fresh weight) and firmness $\left(3.33 \pm 1.08 \mathrm{~kg} / \mathrm{cm}^{2}\right)$ at the end of the 9 days storage period. Maximum acceptability in terms of colour (7.66) retained by GA (10\%) followed by $5 \%$ GA (7.48) coating at the end of the storage. These results suggest that application of GA $10 \%$ coating was effective for retaining physico-chemical qualities of guava and the preservation of the sensory characteristics of the fruit during storage at room temperature.
\end{abstract}

\section{Introduction}

Guava known as 'Apple of the Tropics' is an important commercial fruit crop of India. It is the fourth most important fruit crop after mango, banana and citrus. India is the world's largest producer of guava with an annual production of 4.05 million metric tons from 0.26 million hectare area (NHB, 2015). The guava is rich in vitamins such as vitamins $\mathrm{A}$, $\mathrm{B}_{1}$ (thiamine), $\mathrm{B}_{2}$ (riboflavin) and $\mathrm{C}$ (ascorbic acid). The vitamin $\mathrm{C}$ content of guava fruit is 2-5 times higher than that of citrus fruit. The fruit is good source of pectin, fibre, calcium and phosphorus (Singh, 2005). Cultivar Shweta is the selection from half sib population of Apple Color guava variety.

Its fruits are medium size (200-225g), having snow white flesh, high TSS (12.5-13.8 ${ }^{\circ}$ Brix) and high vitamin $\mathrm{C}$ content $(300 \mathrm{mg} / 100 \mathrm{~g}$ pulp). Good quality, high yield and wider adaptability led to fast expansion in area of cv. Shweta in Maharashtra, Andhra Pradesh, Punjab and Haryana (http://www.cish.res.in/ varieties_develop.php) 
Guava fruits are highly accepted by the consumers in firm, mature and green peel colour stage for fresh consumption. Fruits show peak in respiration and ethylene production after harvesting owing to its climacteric behavior (Bashir and Abu-Goukh, 2003). Under ambient conditions guava fruit become overripe and mealy within 4-5 days, whereas, in cold storage below $10{ }^{\circ} \mathrm{C}$ severe chilling injury symptoms may appear in the form of skin surface pitting and flesh browning (Wang et al., 2009; Mahajan et al., 2009). These drawbacks limit long distance transportation, storage and warrant immediate marketing and consumption after harvest. At present, there are no reliable methods for prolonging the shelf life and retaining the quality of guava fruit under ambient conditions.

The edible coatings have been used to extend shelf life, retain freshness and keeping quality of fruits. Coatings act as an obstruction on the fruit surface, and regulate the internal gas atmosphere, reducing moisture loss, retain peel pigments and delaying fruit ripening (Bourtoom, 2008). Gum arabic also known as acacia gum is a natural gum obtained from Acacia species secretion. It is a mixture of polysaccharides and glycoproteins used in industries for film forming, emulsification and encapsulation properties. Earlier, shelf life has been extended by applying gum arabic coating in tomato (Ali et al., 2010), mango (Khaliq et al., 2015), sweet cherry (Mahafaudi and Hamdi, 2014) and green chillies (Chitravathi et al., 2014). Therefore, the aim of this study was to understand the effect of gum arabic coating on extending shelf life, retaining freshness and quality of guava fruits during storage under ambient conditions.

\section{Materials and Methods}

Fully mature, green and firm fruits of Shweta variety were procured from the experimental orchard of ICAR-Central Institute for Subtropical Horticulture, Lucknow during January, 2017. Healthy fruits $(n=360)$ of uniform size without any defect were washed and spread on the clean floor for air drying. The experiment involves 4 treatments, each with three replications. The 360 fruits were divided into 4 lots of 90 fruits for each treatment. The three lots of fruits were dipped in $2.5,5$ and $10 \%$ aqueous solution of gum arabic for 5 minutes, remaining one lot was dipped in water which was kept as control. Following each treatment fruits were air dried, packed in corrugated fibre board boxes (CFB) and stored under ambient conditions (average day/night temperature 21.5/12.8 ${ }^{\circ} \mathrm{C}$ and humidity 52\%) for 9 days. After 3, 6 and 9 days fruits $(n=30)$ from each treatment were sampled at random and used for physical, quality and sensory parameters analysis.

Physical analysis: Post-treatment physiological loss in weight (PLW) in both coated and control fruits were recorded at each sampling interval up to 9 days. PLW was calculated as the difference between the initial weight of fruit (on day-0) and the weight of fruits at the time of sampling, expressed in terms of percentage. Firmness in coated and uncoated fruits was measured at three points per fruit using a 'McCormick fruit tester FT 327 ' penetrometer with head diameter of 11 $\mathrm{mm}$. Fruit firmness was expressed in $\mathrm{kg} / \mathrm{cm}^{2}$.

Chemical analysis: Total Soluble Solids (TSS) were measured by using hand refractometer (Erma, Japan), while titratable acidity by titrimetric methods using $0.1 \mathrm{~N} \mathrm{NaOH}$ (Ranganna, 2000). Peel chlorophyll was extracted in $80 \%$ acetone and estimated in spectrophotometer as method described by Pandey et al., (2015) with minor modifications. Ascorbic acid in fruit pulp was estimated by titrimatric method using 2, 6dichlorophenol indophenols dye solution and total phenol content was analyzed using Folin 
and Ciocalteu phenol reagent method (Ranganna, 2000). Sensory evaluation of the fruit for taste, colour and overall acceptability for all the samples was done at 3 days interval during storage. Seven panelists were asked to score the difference between samples where 0-2 represented extreme dislike; 3-5 fair; 6-8 good; and 9 excellent for fruit colour, taste and overall acceptability. The experiment was conducted using a completely randomized design (CRD) with four replications. The data obtained were subjected to statistical analysis by using 'Statistical Software Package for Agricultural Research Workers' software at $5 \%$ significance level.

\section{Results and Discussion}

\section{Physical parameters}

The weight loss of fruits coated with gum arabic was lower than control fruits irrespective of concentration of coating solution (Fig. 1). A significant difference in weight loss was observed between the coated and control fruits. At the end of 9 days period minimum weight loss was observed in $10 \%$ gum arabic coated fruits $(15.46 \pm 1.95 \%)$ followed by $5 \%$ gum arabic treated fruits $(17.67 \pm 1.42 \%)$ while in control fruits $(19.95 \pm 2.35 \%)$ maximum weight loss was observed. Weight loss was more pronounced during initial 3 days of storage, after that comparatively steady loss was observed in both coated and uncoated fruits.

The weight loss during storage might be due to water loss by transpiration and other physiological mechanism, the substrate loss by respiration (Juhaimi et al., 2012). The slow decline in weight loss of coated fruits was due to the formation of a semi-permeable barrier against gases like oxygen, carbon dioxide, moisture and other solute movement due to which it reduces respiration, moisture loss and oxidation (Baldwin et al., 1999, Ali et al.,
2010). The findings are in line with the results of Murmu and Mishra (2016) in 'Lalit' guava coated with sodium caseinate and tulsi extract and Ali et al., (2010), who observed less weight loss in tomato fruits coated with $10 \%$ and $15 \%$ gum arabic.

Firmness significantly declined in both coated and uncoated fruits as storage period progressed (Fig. 1). At the end of the storage, maximum firmness $\left(8.12 \pm 1.67 \mathrm{~kg} / \mathrm{cm}^{2}\right)$ was observed in $10 \%$ gum arbic coated fruits followed by $5 \%$ gum arabic $(7.17 \pm 1.32$ $\mathrm{kg} / \mathrm{cm}^{2}$ ) coated fruits whereas minimum firmness $\left(3.33 \pm 1.08 \mathrm{~kg} / \mathrm{cm}^{2}\right)$ was estimated in control fruits. Rapid decline in firmness in control fruits was observed after 3 days of storage, whereas $5 \%$ and $10 \%$ GA treated fruits maintained significantly higher firmness until 9 days of storage. Decrease in firmness of fruits is due to pectinase and hydrolase enzyme activity that leads to degradation in cell structure, cell wall composition and inter and intracellular materials (Seymour et al., 1993). Inhibition of loss of firmness by edible coatings has been reported for various fruits including $10 \% \mathrm{GA}$ in mango (Khaliq et al., 2015), 10 and 15\% GA in tomato (Ali et al., 2010), combined treatment of GA and chitosin in banana (Maqbool et al., 2011). In this study, GA 5\% and 10\% coated fruits showed higher firmness than the control fruits and this may be due to thick coating which created a modified atmosphere around the fruit surface as a result reduced changes in pectin substances and activity of cell wall degrading enzymes.

\section{Biochemical parameters}

Ascorbic acid content was increased during initial three days of storage in all fruits irrespective of treatments. After three days of storage, ascorbic acid content was reduced considerably in control fruits, whereas in coated fruits it remains stable (Fig. 2a). 
Fig.1 Effect of GA coatings on (a) physiological loss in weight and (b) fruit firmness during storage at room temperature

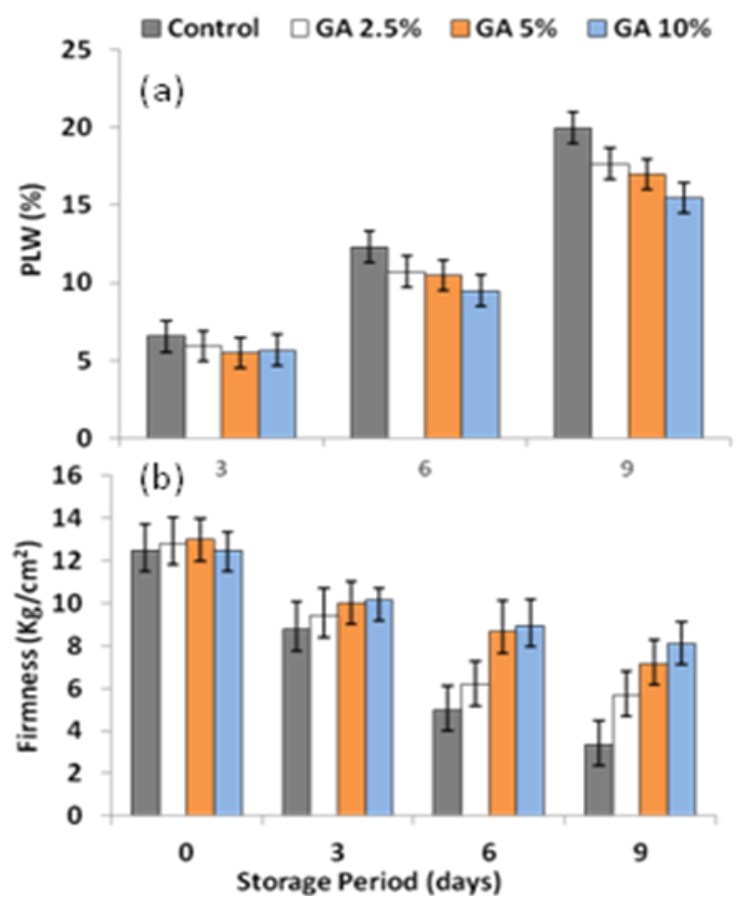

Fig.2 Effect of GA coatings on (a) ascorbic acid contents, (b) total chlorophyll contents, (c) total titrable acidity and (d) total soluble solids
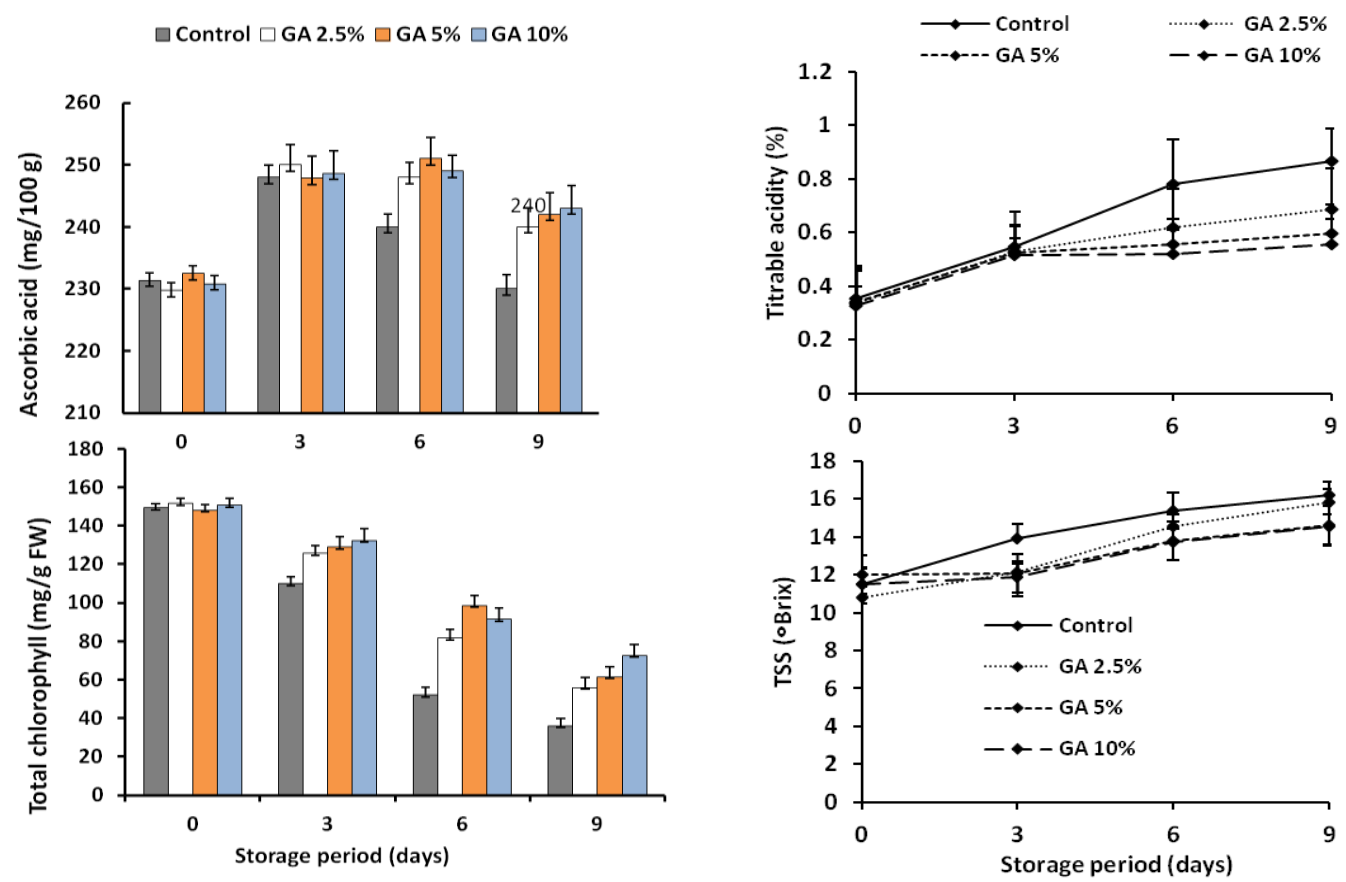
Table.1 Effect of different concentration of GA coatings on sensory score of fresh fruits stored for 9 days at room temperature

\begin{tabular}{|l|c|c|c|c|c|c|c|c|c|}
\hline Treatments & \multicolumn{4}{|c|}{ Taste $^{*}$} & \multicolumn{3}{c|}{ Colour* } & Overall A cceptability* \\
\hline & 3 day & 6 day & 9 day & 3 day & 6 day & 9 day & 3 day & 6 day & 9 day \\
\hline Control & $7.61^{\mathrm{a}}$ & $6.8^{\mathrm{a}}$ & $5.59^{\mathrm{a}}$ & $8.20^{\mathrm{a}}$ & $7.48^{\mathrm{a}}$ & $6.77^{\mathrm{a}}$ & $7.48^{\mathrm{a}}$ & $6.77^{\mathrm{a}}$ & $6.33^{\mathrm{a}}$ \\
\hline GA $2.5 \%$ & $7.5^{\mathrm{a}}$ & $7.30^{\mathrm{b}}$ & $6.83^{\mathrm{b}}$ & $8.45^{\mathrm{a}}$ & $8.25^{\mathrm{b}}$ & $7.13^{\mathrm{b}}$ & $8.01^{\mathrm{b}}$ & $7.25^{\mathrm{b}}$ & $7.0^{\mathrm{b}}$ \\
\hline GA 5\% & $8.20^{\mathrm{a}}$ & $7.35^{\mathrm{b}}$ & $7.33^{\mathrm{c}}$ & $8.55^{\mathrm{a}}$ & $8.20^{\mathrm{b}}$ & $7.48^{\mathrm{c}}$ & $8.56^{\mathrm{b}}$ & $7.54^{\mathrm{b}}$ & $7.13^{\mathrm{b}}$ \\
\hline GA 10\% & $8.00^{\mathrm{a}}$ & $7.83^{\mathrm{c}}$ & $7.38^{\mathrm{c}}$ & $8.53^{\mathrm{a}}$ & $8.33^{\mathrm{b}}$ & $7.66^{\mathrm{d}}$ & $8.35^{\mathrm{b}}$ & $7.88^{\mathrm{c}}$ & $7.48^{\mathrm{c}}$ \\
\hline CD at 5\% & NS & 0.28 & 0.32 & NS & 0.38 & 0.26 & 0.31 & 0.45 & 0.18 \\
\hline
\end{tabular}

*Average of four replicates

After six days, ascorbic acid content declined in coated fruits and at the end of the storage $10 \%$ GA treated fruits retained maximum ascorbic acid $(243 \pm 3.27 \mathrm{mg} / \mathrm{g})$, whereas control fruits retained lowest ascorbic acid content $(230 \pm 2.21)$. In guava ascorbic acid content increases with maturity and ripening, however when fruit reached full ripe stage, the ascorbic acid content starts to diminish (Tandon et al., 1989). The delayed retention of ascorbic acid in coated fruits advocates that the coating slowed down the rate of ascorbic acid degradation. Similar retention of ascorbic acid content has been reported in GA coated tomato fruits (Ali et al., 2010).

Chlorophyll content in guava skin is related with the consumer appeal and preference. In the present study chlorophyll content decreased as storage period progressed. In case of uncoated fruits, drastic reduction in chlorophyll content was observed after 3 days of storage and it was significantly lower than $10 \%$ GA coated fruits (Fig. 2b). At the end of the storage period, minimum $(36.21 \pm 3.54$ $\mathrm{mg} / \mathrm{g}$ fresh weight) total chlorophyll content was observed in uncoated fruits while maximum total chlorophyll content $(72.55 \pm 4.10 \mathrm{mg} / \mathrm{g})$ was estimated in $10 \% \mathrm{GA}$ coated fruits. Results indicate that the coating can delay the degradation of chlorophyll. Similar results were observed by Chitravathi et al., (2014) in shellac based edible coated green chilli.
Generally titratable acidity of fruits usually tends to decrease during fruit ripening. Increase in acidity has been reported in few varieties of guava (Bashir and Abu-Goukh, 2003; Mahmood et al., 2012). Similar results were reported in present investigation where acidity in both coated and uncoated fruits increased as storage period progressed (Fig. 2c). On $9^{\text {th }}$ day of storage, titratable acidity in uncoated fruit was $0.82 \%$, whereas it was $0.50 \%$ in $10 \%$ GA coated fruits. The enhancement in titratable acidity in coated fruits might be suppressed due to reduction in the respiration rate during storage. The TSS was significantly higher in uncoated fruits as compared to coated fruits and reduction in TSS in coated fruit was directly proportional to the concentration of the coating (Fig. 2d).

The hike in TSS can be due to moisture loss from the fruits and conversion of organic acids into sugars (Gorny and Kader, 1998). The minimum TSS $\left(14.56^{\circ}\right.$ Brix) at the end of the storage period was observed in fruit coated with $10 \% \mathrm{GA}$, whereas the maximum TSS (16.2 ${ }^{\circ}$ Brix) was estimated in uncoated fruits. It showed that the coatings provided a semi-permeable film around the fruit, modifying the internal atmosphere by reducing $\mathrm{O}_{2}$ and/or elevating $\mathrm{CO}_{2}$ and suppressing ethylene production. Reduction in respiration rates also slow down the synthesis and use of metabolites resulting in lower TSS (Ali et al., 2010). 


\section{Sensory parameters}

The sensory evaluation was carried out at post-harvest laboratory of institute by 7 panelists to evaluate colour, taste and overall acceptability of fruits during storage. The uncoated and 10\% GA coated fruits showed significant difference in colour, taste and overall acceptability after $6^{\text {th }}$ and $9^{\text {th }}$ day of storage (Table 1). The 10\% GA coated fruits showed significantly higher score for colour (7.66), taste (7.48) and overall acceptability (7.38) as compared to uncoated fruits on $6^{\text {th }}$ and $9^{\text {th }}$ day of storage. Similar results were observed by El-Anany et al., (2009) when they treated 'Anna' apples with GA coating. The results suggest that GA can be used as edible coating to improve sensory quality and prolonging freshness of guava fruits during storage at room temperature.

The results of this study indicate that guava fruits coated with $10 \%$ GA showed a significant reduction in weight loss (\%) and delay in change in firmness, titratable acidity, soluble solids concentration and colour during storage at room temperature as compared to uncoated control fruit. In addition, sensory evaluation showed that $10 \%$ gum arabic coating maintained the overall quality of the fruit fruit during storage.

\section{References}

Ali, A., Maqbool, M., Ramachandran, S. and Alderson, P. G. 2010. Gum arabic as a novel edible coating for enhancing shelf-life and improving the postharvest quality of tomato (Solanum Lycopersicum L.) fruit. Postharvest Biology and Technology, 58(1), 42-47.

Baldwin, E.A., Burns, J.K., Kazokas, W., Brecht, J.K., Hagenmaier, R.D., Bender, R.J. and Pesis, E. 1999. Eff ect of two edible coating with diff erent permeability characteristics on mango
(Mangifera indica L.) ripening during storage. Postharvest Biol. Tech. 17: 215-26.

Bashir H.A., Abu-Goukh A. A., 2003. Compositional changes during guava fruit ripening. Food Chem, 80: 557563.

Bourtoom, T., 2008. Review Article: Edible films and coatings: characteristics and properties. Int. Food Res. J. 153: 237248.

Chitravathi, K., Chauhan, O.P. and Raju, P.S., 2014. Post-harvest shelf-life extension of green chillies (Capsicum annuит L.) using shellac-based edible surface coatings. Postharvest Biology and Technology, 92: 146-148.

El-Anany, A.M., Hassan, G.F.A., Rehab Ali, F.M., 2009. Effects of edible coatings on the shelf-life and quality of Anna apple (Malus domestica Borkh) during cold storage. J. Food Technol., 7, 5-11.

Gorny, J. R. and Kader A. A., 1998. Fresh-cut products: maintaining quality and safety, University of California Davis, Workshop September 15-16 (1998), 4:12-14.

Juhaimi, F.A., Ghafoor, K. and Babiker, E.E., 2012. Effect of gum arabic edible coating on weight loss, firmness and sensory characteristics of cucumber (Cucumis sativus) fruit during storage. Pak. J. Bot., 44(4): 1439-1444.

Khaliq, G., Mohammad, M.T.M., Ding, P., Ghazali, H.M. and Ali, A. 2015. Effect of gum arabic coating combined with calcium chloride on physico-chemical and qualitative properties of mango (Mangifera indica L.) fruit during low temperature storage. Scientia Horticulturae, 190: 187-194.

Mahafaudi, N. and Hamdi, S. 2014. Use of almond gum and gum arabic as novel edible coating to delay postharvest ripening and to maintain Sweet Cherry 
(Prunus avium) quality during storage. 39(6): 1499-1508.

Mahajan, B.V.C., Sharma, S.R., Dhall, R.K., 2009. Optimization of storage temperature for maintaining the quality of guava. J. Food Sci. Technol. 46: 604-605.

Mahmood T, Anwar F, Abbas M, Boyce, M.C., Saari, N., 2012. Compositional variation in sugars and organic acids at different maturity stages in selected small fruits from Pakistan. Int. J Mol. Sci., 13:1380-1392.

Maqbool, M., Ali, A., Alderson, P.G., Zahid, N., Siddiqui, Y., 2011. Effect of a novel edible composite coating based on gum arabic and chitosan on biochemical and physiological responses of banana fruits during cold storage. J. Agric. Food Chem. 59: 5474-5482.

Murmu, S.B. and Mishra, H.N. 2016. Optimization of the arabic gum based edible coating formulations with sodium caseinate and tulsi extract for guava. LWT - Food Sc. \& Tech., 80: 271-279.

Pandey, V., Abhishek C., Pandey, H. K. and M. Nasim 2015. Estimation of ascorbic acid, B carotene, total chlorophyll, phenolics and antioxidant activity of some European vegetables grown in mid hill conditions of western Himalaya. Journal on New Biological Reports, 4: 238-242.

Ranganna, S. (2000). Handbook of Analysis and Quality Control for Fruit and Vegetable Products. $2^{\text {nd }}$ edn. New Delhi, India: Tata McGraw Hill Publishing Company Ltd.

Singh, G., 2005. Strategies for improved production in guava. In: Kishun, R., Mishra, A.K., Singh, G., Chandra, R. (Eds.), Proceeding of $1^{\text {st }}$ International Guava Symposium. CISH, Lucknow, India, pp. 26-39.

Tandon, D.K., Singh, B.P., Kalra, S.K., 1989. Storage behaviour of specific gravity graded guava fruits. Sci. Hortic. 41: 3541.

Wang, Z, Duan, H. and Hu, C. 2009. Modelling the respiration rate of guava (Psidium guajava $\mathrm{L}$ ) fruit using enzyme kinetics, chemical kinetics and artificial neural network. Eur Food Res Technol, 229(3): 495-503.

\section{How to cite this article:}

Gurjar, P.S., Bharati Killadi, J. Lenka and Shukla, D.K. 2018. Effect of Gum Arabic Coatings on Physico-Chemical and Sensory Qualities of Guava (Psidium guajava L) cv. Shweta. Int.J.Curr.Microbiol.App.Sci. 7(05): 3769-3775. doi: https://doi.org/10.20546/ijcmas.2018.704.424 